\title{
Reform of Rules of Private International Law in Manitoba:
}

\section{A Comparative Perspective}

\author{
Anthony Gray \\ School of Law \\ University of Southern Queensland \\ E-mail: Anthony.Gray@usq.edu.au
}

\begin{abstract}
This paper is based on reform recommendations contained in a 2009 report by the Manitoba Law Reform Commission into the rules of private international law. The reform recommendations relate to (a) whether a flexible exception should be applied in relation to the application of the law of the place of the wrong in torts cases; (b) whether the rules regarding the classification of limitation periods as either substantive or procedural should be codified; and (c) that the rules in relation to the exercise of jurisdiction contained in the Uniform Law Conference of Canada be adopted. In critiquing the Commission's proposals, the law in these areas in other jurisdictions, including the United States, Europe (including the United Kingdom), and Australia are considered and compared.
\end{abstract}

Keywords: Private international law, Flexible exception, Choice of law in tort, Forum non conveniens

\section{Introduction}

In January 2009, the Manitoba Law Reform Commission released its Report on reforms to the rules of private international law (Note 1). In this paper, I explain the suggested reforms, before comparing them with developments in other jurisdictions in relation to similar issues. I then draw conclusions as to the efficacy of the proposed reforms.

\section{Choice of Law Rule in Tort}

\subsection{Current Law}

As readers will be aware, a difficult issue can arise when an alleged tort is committed with links to more than one jurisdiction. It must be decided which laws are to apply to resolve the dispute. The choice made can of course have very important consequences for the resolution of the issues, and often the parties in dispute disagree as to which law should apply.

The original approach taken derives from the judgment of Willes $\mathrm{J}$ in Phillips $v$ Eyre (Note 2) where it was found that in order to found a suit in one jurisdiction (the forum) for a wrong alleged to have been committed elsewhere, the wrong must have been of such a character that it would have been actionable if committed in the forum, and not justifiable by the law of the place where it was done. This rule, which came to be known as the double actionability approach, was adopted in many jurisdictions, (Note 3) including Canada. (Note 4)

Fundamental change occurred in 1994 when the Supreme Court of Canada decided Tolofson v Jensen; Lucas v Gagnon (Tolofson).(Note 5) There the Supreme Court abandoned the Phillips approach, favouring a territorial approach where the law of the place of the wrong would be applied, at least in the vast majority of cases. The court favoured such an approach because it was consistent with notions of territorialism whereby a state has jurisdiction within its own land mass, it was consistent with judicial comity, and the rule was certain, easy to apply and predictable, and meet the normal expectations of the parties. (Note 6)

The Court next considered whether any exceptions should be created to the (new) general rule whereby the law of the place of the wrong was applied. (For ease of reference, I will refer to this as the 'flexible exception'). It noted that in other jurisdictions, including the United States and United Kingdom, a proper law approach had been adopted, whereby the law of the jurisdiction which had a closer connection to the parties and the dispute might apply, either as the approach to be taken, or as an exception to the general rule favouring the law of the place of the wrong. The court noted the uncertainty inherent in such an approach and its potential to create delays and anomalies.(Note 7) A majority of the court concluded that an exception should not exist to the general rule favouring the law of the place of the wrong in respect of disputes involving more than one province, (Note 8) but was more open to an exception in respect of disputes involving more than one nation. This was because, in such cases, 'a rigid rule on the international level could give rise to injustice ... I am not averse to retaining a discretion in the court to apply our own law to deal with such circumstances. I can, however, imagine few cases where this would be necessary'. (Note 9) 
In subsequent cases, there are several examples where this exception has been applied in international cases, such that the law of the forum was applied rather than the law of the place of the wrong, a State of the United States. (Note 10) There is one reported case where the exception was applied in an intra-national case, so that forum law applied rather than the law of the place of the wrong. (Note 11)

\subsection{Commission's Recommendations and Reasoning}

The Manitoba Law Reform Commission recommends legislating for the flexible exception to the application of the law of the place of the wrong described above, and for it to be applicable to both international and interstate torts cases. It agrees that the general rule should favour the law of the place of the wrong. The place of the wrong is the 'country' (although the recommendations apply to intra-Canadian cases also) in which the elements constituting the tort in question occur. The Report provides specific rules to determine this where elements occur in different 'countries'. In respect of a personal injuries action, this is (generally) where the individual was when they sustained the injury; for damage to property it is (generally) where the property was when damaged, and in other cases it is the country in which the most significant element or elements of the tort occurred. There is also recommended a residual exception, even in personal injuries and property cases, to apply the law of another country that is more closely connected with the issues than the indicated country. (Note 12)

Presumably the Commission believes there is a need for further flexibility in departure from the law of the place of the wrong than was expressed in Tolofson, or which has actually been demonstrated in cases subsequent to Tolofson. The Commission does not point out specific cases where it believes unjustness has occurred as a result of applying the Tolofson approach. It does not make express, but perhaps would accept, the traditional argument against a blanket application of the law of the place of the wrong, which is that sometimes that place is purely fortuitous, and/or that place has little or no actual connection with the parties, other than the fact that a dispute involving them occurred there. The facts of well-known cases such as Chapin v Boys (Note 13) and Babcock v Jackson (Note 14) are prime examples of this difficulty.

\subsection{Other Jurisdictions}

As has been acknowledged, the United Kingdom legislated to overcome the rules of double actionability. Lord Wilberforce had pointed out in Boys $v$ Chaplin that

To fix the liability of two or more persons according to a locality with which they may have no more connection than a temporary, accidental and perhaps unintended presence, may lead to an unjust result. (Note 15)

The Private International law (Miscellaneous Provisions) Act 1995 (UK) provides in respect of most torts cases (except defamation), the law of the place of the wrong should be applied to resolve the case. This is generally the place in which the events constituting the tort occurred. Particular rules, similar to those recommended above by the Manitoba Law Reform Commission, apply to resolve this question where those events occur in different countries. A flexible exception is provided where, having considered the significance of the factors connecting a tort with the place of the wrong and connections with another country, it is substantially more appropriate for the law of the other country to apply. Relevant factors include matters relating to the parties, to any events constituting the tort, or any of the circumstances or consequences of those events. (Note 16)

A very recent development has been the introduction of the Rome Convention on the Law Applicable to Non-Contractual Obligations (Rome II), Regulation EC 864/2007, which became effective in January 2009. The Convention states the general rule that the law of the country where the damage has occurred applies to resolve an international torts case. (Note 17) Two exceptions to the general rule are provided - Article 4(2) states that where the plaintiff and defendant are resident in the same country, the law of that country should apply. (Note 18) Further, despite the general rule, where another country is manifestly more closely connected with the dispute than the place of the wrong, the law of that country should be applied, (Note 19) in cases where the Convention is applicable.

In Australia, there had been a suggestion from some of the judges in Breavington $v$ Godleman that there was a need for a so-called flexible exception to avoid in some cases the law of the place of the wrong on the basis that it might be arbitrary:

To fix the liability of two or more persons according to a locality with which they may have no more connection than a temporary accidental and perhaps unintended presence may lead to an unjust result ... The mechanical application of the (law of the place of the wrong) cannot do justice to the infinite variety of cases in which persons come together in a foreign jurisdiction from different legal backgrounds ... the qualified or flexible application of the law of the place of the wrong copes with the incidents of tort law in the modern age of travel when the place of the accident may be fortuitous ... and the parties may have no substantial connection with the law of that place or with that place at all. (Note 20) 
In John Pfeiffer Pty Limited v Rogerson, (Note 21) Australia's version of Tolofson, the High Court of Australia officially abandoned the double actionability approach in favour of the application of the law of the place of the wrong. However, in doing so, it rejected a flexible exception for reasons similar to those expressed in Tolofson:

Adopting any flexible rule or exception to a universal rule would require the closest attention to identifying what criteria are to be used to make the choice of law. Describing the flexible rule in terms which are 'real and substantial' or 'most significant' connection with the jurisdiction will not give sufficient guidance to courts, to parties, or to those like insurers who must order their affairs on the basis of predictions about the future application of the rule. What emerges very clearly from the United States experience in those States where the proper law of the tort theory has been adopted is that it is has led to very great uncertainty. That can only increase the cost to parties, insurers and society at large. (Note 22)

Pfeiffer was decided in the context of an inter-state (province) dispute. In a subsequent case involving international aspects, it had been expected that the High Court would also rule out a flexible exception in such cases. However, the joint reasons suggested that

questions that might be caught up in the application of a 'flexible exception' to a choice of law rule fixing upon the law of the place of the wrong in practice may often be subsumed in the issues presented on a stay application, including one based on public policy grounds. (Note 23)

These comments are very similar to the joint reasons of the Supreme Court of Canada in Tolofson in doubting the need for a flexible exception in international cases. (Note 24)

Most recently in Neilson v Overseas Projects Corporation of Victoria Ltd, (Note 25) the High Court was faced with litigation brought by an Australian resident living in China, who was injured there while staying in accommodation provided by her husband's Australian-registered company. That company was insured for relevant purposes by an Australian insurance company. The plaintiff alleged that the premises were unsafe. Clearly the place of the alleged wrong was China, and applying the rules set out above, the law of China should have been applied to resolve the dispute. However, the court ended up applying Australian law to resolve the dispute, by enlivening the controversial renvoi doctrine, (Note 26) and by applying a controversial presumption that, in the absence of evidence, foreign law was the same as local law. This case might be seen as a 'red flag' to suggest that some kind of flexible exception is required, as in fact one of the judges acknowledged. (Note 27) One leading commentator notes the case as an example of 'desperate measures judges are prepared to take to get to the lex fori'. (Note 28)

In the United States, the First Restatement (Note 29) called for the strict application of the law of the place of the wrong. However, subsequently there was the important decision of the New York Court of Appeals in Babcock v Jackson. (Note 30). That case involved an action by one New York resident against another in relation to an accident that occurred in Ontario. The Court applied New York law as the jurisdiction 'which, because of its relationship or contact with the occurrence or the parties has the greatest concern with the specific issue raised in the litigation'. (Note 31)

This decision influenced the Second Restatement, which embraces the proper law of the tort, specifying a range of factors to be considered in deciding which law to be applied in such cases. These include the place where the injury occurred, the place where the conduct causing the injury occurred, the domicile, residence, nationality, place of incorporation and place of the business of the parties, and the place where the relationship, if any, between the parties is centred. (Note 32) This proper law approach is the dominant theory applied in the United States, with a small number of states continuing to apply the law of the place of the wrong without exception. (Note 33)

\subsection{Commentary on Commission's Proposal}

I support the Commission's proposal. The experience in other jurisdictions, borne out by the facts of cases such as Chaplin, Babcock and Neilson, is that sometimes the place where the wrong occurs is fortuitous. Anomalous results could arise if courts were forced to routinely apply the law of that place, without exception. Some flexibility is required. And surely this issue of the place of the wrong being 'fortuitous' is equally applicable to inter-provincial cases as international cases.

The principle of territoriality, that a state has the power to regulate activities and events that occur within its boundaries, is well established and recognised. As has been noted, it accords with the expectations of most individuals. Its essential soundness should be reflected in a starting position that the law of the place of the wrong is the applicable law. This is the approach taken by the United Kingdom legislation and Rome II. This approach is favoured over the American 'centre of gravity' approach, which counts the place of the wrong as just one of the factors to be considered, and accorded no superiority. In my view, the starting point should be that the law of the place of the wrong is the applicable law. In my view, and accepting that reasonable minds may well differ, this starting point provides the appropriate balance between certainty and the need for some flexibility to do justice in a particular case. This rule can be displaced if various factors suggest a closer connection with another jurisdiction. 
It is suggested that the Commission might also have considered a specific situation in Rome II, where the residence of the plaintiff and defendant is common, and is not the place of the wrong. In such cases, Rome II directs that the law of the common domicile should apply, based on a notion that the place of the wrong has little or no interest in the outcome of the case, since it does not affect its residents or (presumably) its insurance companies. This was also the situation in the Australian case Neilson, where both the plaintiff and defendant were resident in Australia, arguing over events that occurred in China. It was said there that, as demonstrated by its choice of law rules, China had little interest in the outcome of the litigation. It is suggested then that, if there is to be some statutory reform in this area, that provision should be made for the specific situation of a common domicile between plaintiff and defendant different from the place of the wrong.

I note that no exception is provided to the application of the law of the place of the wrong based on notions of "public policy'. I support this non-inclusion. There is a danger that, if a public policy exception were allowed, it would simply mask a preference for forum law. This point is acknowledged by Jean-Gabriel Castel QC

Of course, there is always the possibility of resorting to public policy to avoid the application of the foreign lex loci delicti. Thus, where the forum has a serious relationship to the issues or the parties, it could apply its own law and in so doing base its choice on considerations of public policy as, for instance, if the lex loci delicti gave little or no recovery at all. (Note 34)

In my view, it should not be enough to discard the application of the law of the place of the wrong that it doesn't provide a remedy that the forum court might think should exist. The consequence of a strong application of territorialism sometimes does mean that the result is different to what would have occurred had forum law been applied. This is not a reason for refusing to apply the law of the place of the wrong. As the joint reasons in Tolofson concluded:

To permit the court of the forum to impose its views over those of the legislature endowed with power to determine the consequences of wrongs that take place within its jurisdiction would invite the forum shopping that is to be avoided if we are to attain the consistency of result an effective system of conflict of laws should seek to foster. (Note 35)

Perhaps there is a very limited need for a public policy exception, but I believe it must be tightly constrained lest it be used as a mask to give preference to forum law. (Note 36)

\section{Limitation Periods}

\subsection{Current Law}

Traditionally, limitation periods were treated differently according to whether they extinguished the right on which the claim was based, or merely provided that no remedy existed for the infringement of the right. The former were classified as substantive, with the latter being classified as procedural. This is important because it is accepted that matters of substance are governed by the law of the cause (here, at least primarily, the law of the place of the wrong), while matters of procedure were a matter for the forum. (Note 37)

In Tolofson, this distinction was abandoned by the Supreme Court. It spoke of the differentiation between 'what is part of a court's machinery and what is irrevocably linked to the product', and considered the reason for the distinction, which was primarily about convenience and efficiency. The court did not find a distinction between right and remedy convincing. As a result, the relevant limitation period to be applied was the one provided for by the law of the cause, primarily the law of the place of the wrong. (Note 38)

The Tolofson approach to limitation periods has been followed by courts in both interprovincial and international torts cases. However, legislative attempts have been made in some provinces to change the rules, (Note 39) and in one recent decision, Vogler v Svendroi, the Nova Scotia Court of Appeal characterised provisions determining when an action is deemed to have commenced for statute of limitations purposes as procedural, to be governed by forum law rather than the law of the cause (Wyoming). (Note 40)

\subsection{Commission's Recommendations and Reasoning}

The Commission agrees with the approach taken in Tolofson, and suggests it should be codified, as has occurred in Ontario. (Note 41)

\subsection{Other Jurisdictions}

There has been real difference of opinion in the United Kingdom regarding where the line is to be drawn between matters of substance and matters of procedure. One way in which this can be shown is by considering the way in which the law is expressed by the one of the leading texts. While Dicey in the first edition states that English lawyers 'give the widest possible extension to the meaning of the term 'procedure', (Note 42) by the fourteenth edition the view is that 'the practice of giving a broad scope to the classification of a matter as procedural has fallen into disfavour because of the tendency to frustrate the purposes of choice of law rules'. (Note 43) Legislation was introduced in 1985 to declare 
that foreign statutes of limitation should be applied as substantive law. (Note 44) The 1995 Act did not change the previous position regarding the distinction between substance and procedure. (Note 45)

The Rome Convention on the Law Applicable to Non-Contractual Obligations (Rome II), effective from January 2009, provides in Article 15(h) that the issue of the manner in which an obligation may be extinguished, including the commission, interruption and suspension of limitation periods, are matters for the law of the cause (primarily the law of the place of the wrong, as discussed above). This rule is contrary to the finding of the judge in Vogler that a rule regarding commencement of a limitation period is a question of procedure.

A slim majority of the High Court of Australia in McKain $v R W$ Millar and Co (SA) Ltd (Note 46) applied the traditional distinction between a statute of limitations that merely barred a remedy (procedural) and one that extinguished the right (substantive). In dissent, Mason CJ pointed out that the view of the majority would frustrate the purpose of choice of law rules, encourage forum shopping, and reflected a doctrine developed when international judicial comity was not valued. It was sensible for courts to apply their own rules of procedure from an efficiency perspective. (Note 47) Deane J in dissent found the distinction between right and remedy confounded good sense and reality. (Note 48)

These dissenting views were accepted by the High Court in John Pfeiffer Pty Ltd v Rogerson, (Note 49) where the court found that the plaintiff 'cannot ask that the courts of the forum adopt procedures ... of a kind which their constituting statutes do not contemplate'. (Note 50). States also enacted legislation to overcome the effect of McKain, at least in interstate tort cases. (Note 51)

In the United States, the Restatement (Second)(applied by most states) provides a general rule that, unless exceptional circumstances exist making such a result unreasonable, the forum should apply its own statute of limitations barring the claim, and its own statute of limitations permitting the claim, unless (a) maintenance of the claim would serve no substantial interest of the forum, and (b) the claim would be barred under the statute of limitations of a state having a more significant relationship to the parties and the occurrence. (Note 52)

An example of the general application of the Restatement position occurred in Franchise Tax Board California v Hyatt, (Note 53) where the parties were litigating over wrongs allegedly committed primarily in California. The action was commenced in Nevada, and the United States Supreme Court found the Nevada court was correct in applying its limitation rules, rather than those of California (including state sovereign immunity rules). An example of the application of the exception being applied is Huynh v Chase Manhattan Bank, (Note 54) where a California court refused to apply Californian limitation periods because of the lack of connection between the claims and California. The Supreme Court of New Mexico recently applied a New Mexico limitation period in respect of a claim based on an accident in that jurisdiction, although the limitation period related to claims against New Mexico government entities, and this claim was against an Arizona state entity. Arizona law had applied for a different limitation period in respect of claims against Arizona state entities, but this law was not applied to the claim. (Note 55)

\subsection{Commentary on Commission's Proposal}

It is submitted that the Commission's proposal is a good one. The approach of the Supreme Court of Canada in Tolofson was correct, with respect, and should be enshrined in legislation. The concept of what is procedural should, in accordance with clear trends in the United Kingdom, Europe generally, and Australia, be confined to the machinery of proceedings, due to efficiency considerations. By doing so, we minimise the options for forum shopping, and provide for maximum effect to be given to the law of the cause, which is as it should be. The approach of the Restatement (Second), with the continuing primacy it gives to the law of the forum in limitations matters, is seen as out of step with developments elsewhere and is in need of reform.

\section{Jurisdiction}

\subsection{Current Position}

Traditionally, the bases of a court's jurisdiction over a particular defendant have included presence within the jurisdiction, and valid service outside the jurisdiction. In relation to the latter, the Supreme Court of Canada has declared the need to establish a 'real and substantial connection' between the court and the action. (Note 56) It did not define what was meant by this concept. In subsequent cases, several factors have been indicated as relevant in determining whether the connection test is satisfied. (Note 57) However, there is doubt over several matters; including whether or not the real and substantial connection approach is confined to interprovincial matters or applicable also to international matters, (Note 58) whether the traditional grounds of jurisdiction are separate from or subsumed into the real and substantial connection test, (Note 59) and whether the test unacceptably mixes up factors more relevant to a forum non conveniens application into a question of whether a court has jurisdiction or not. (Note 60) Relevant factors in relation to a forum non conveniens application have been set out by the Court. (Note 61) The Supreme Court of Canada has said (Note 62) that the Canadian doctrine of forum non conveniens is consistent with the British common law position espoused in Spiliada Maritime Corp v Cansulex Ltd. (Note 63) 


\subsection{Commission's Recommendations and Reasoning}

The Commission recommends the adoption of the Uniform Law Conference of Canada's Uniform Court Jurisdiction and Proceedings Transfer Act, with a slight amendment. (Note 64) The Act firstly clarifies the bases upon which a court generally (Note 65) has territorial competence, to include (as separate and discrete heads) on the one hand by agreement (or other kind of submission) or residence, (Note 66) and on the other hand that there is a real and substantial connection between the province and the facts on which the proceeding is based. (Note 67) This provision removes the doubt expressed above as to whether the real and substantial connection is an all-consuming test, or a stand alone alternative test. Under the Act, it is clear the latter interpretation is correct. (Note 68)

Section 10 is an important section clarifying the meaning of 'real and substantial connection'. It provides that, without limiting other cases in which such a connection might be shown, a connection will be presumed if:

(a) the case involves rights in immovable or movable property in the jurisdiction

(b) it concerns the administration of an estate of a deceased person in relation to immovable property of the deceased person in the jurisdiction, or movable property of a deceased who was ordinarily resident in the jurisdiction at the time of death;

(c) is brought in relation to a contract in relation to immovable or movable property in the jurisdiction, or movable property of a deceased person who was ordinarily resident in the jurisdiction at the time of death;

(d) is brought against a trustee in relation to a trust with links to the jurisdiction (eg trust property in the jurisdiction is the subject of the claim, trustee is ordinarily resident in the jurisdiction, trust is primarily administered in the jurisdiction etc);

(e) concerns contractual obligations, and they were to be substantially performed in the jurisdiction, or the contract contains a choice of law clause favouring the jurisdiction, or the contract relates to the purchase of property/services for private use, and resulted in solicitation for business in that jurisdiction by the provider;

(f) contains restitutionary obligations that arose primarily in the jurisdiction;

(g) concerns a tort committed in the jurisdiction;

(h) concerns a business carried on in the jurisdiction;

(i) is a claim for an injunction ordering a party to do or refrain from doing anything in the jurisdiction, or in relation to property in the jurisdiction;

(j) is for the determination of personal status or capacity of a person who is ordinarily resident in the jurisdiction;

(k) is for enforcement of a judgment of a court made in or outside the jurisdiction or an arbitral award made in or outside the jurisdiction; or

(l) is for the recovery of taxes or other indebtedness and brought by the Crown of the jurisdiction or by a local authority of the jurisdiction.

It is clear in the explanatory comments that the above are presumptions only, and the defendant still has the right to show that on the particular facts, the connection is not 'real and substantial' despite the above list. (Note 69) On the other side, a plaintiff whose claim does not fit within any of the situations above can still argue that a real and substantial connection exists.

Section 11 provides the rules regarding forum non conveniens. It states that after considering the interests of the parties to the proceeding and the ends of justice, a court may decline to exercise jurisdiction on the ground that a court of another state (defined to include another province or another country) is a more appropriate forum in which to hear the proceeding. In deciding this question, relevant factors include:

(a) the comparative convenience and expense for the parties to the proceeding and for their witnesses in litigating in the court or in any alternative forum;

(b) the law to be applied to issues in the proceeding;

(c) the desirability of avoiding multiplicity of legal proceedings;

(d) the desirability of avoiding conflicting decisions in different courts;

(e) the enforcement of an eventual judgment; and

(f) the fair and efficient working of the Canadian legal system as a whole.

The explanatory comments state the provision is designed to reflect the existing common law, including the factors that have been taken into account by courts in assessing such applications. 


\subsection{Other Jurisdictions}

European Council Regulation (EC) No 44/2001 deals with jurisdiction issues. (Article 70) Article 23 provides for cases of exclusive jurisdiction, in cases involving immovable property within a jurisdiction, issues surrounding companies which have their seat in the jurisdiction, proceedings concerning the validity of entries in public registers within the jurisdiction, proceedings concerning the registration or validity of intellectual property rights applied for in a jurisdiction, or the jurisdiction in which enforcement of a judgment is sought. In such cases, courts of that jurisdiction have exclusive jurisdiction. Apart from these specific cases, the general rule is set out in Article 2. It provides that a person domiciled in a Member State shall be sued in the courts of that Member State.

Exceptional rules are provided for in relation to contractual matters, where the jurisdiction in which performance is/was to occur can hear the matter. (Note 71) In matters of tort, courts of the place where the harmful event occurred or may occur have jurisdiction, and in cases involving trusts, courts of the place where the trust is domiciled have jurisdiction. (Note 72) Other special rules apply to insurance, consumer contracts, and contracts of employment. (Note 73) The Regulation does not deal with the forum non conveniens doctrine; it merely provides that where matters involving the same cause of action and between the same parties are brought in the courts of different member states, any court other than the first one seised should stay its proceedings. (Note 74) Otherwise, the law of member states will be applied in relation to forum non conveniens type applications.

As I have indicated, the British approach is to grant a stay where 'the court is satisfied that there is some other available forum, having jurisdiction, which is the appropriate forum for the trial of the action, ie in which the case may be tried more suitably for the interests of all the parties and the ends of justice'. The more appropriate forum is the one with which the action has the most real and substantial connection. Relevant factors include the availability of witnesses, the law governing the relevant transaction and the places where the parties live or carry on business. (Note 75)

In Australia, originally the basis of a court's jurisdiction was the defendant's presence within the jurisdiction or submission. In relation to service outside of the jurisdiction but within Australia, a writ issued by either the High Court or Federal Court of Australia can be served on any defendant anywhere in Australia. (Note 76) The same result is achieved in respect of proceedings commenced in State and Territory courts by the Service and Execution of Process Act 1992 (Cth). That legislation does not require any territorial connection between the issuing state and the parties or subject matter.

Where proceedings were commenced in a State Supreme Court, application can be made to transfer proceedings to another Supreme Court pursuant to cross-vesting legislation. (Note 77) Similarly where proceedings were commenced in another court, application can be made for a stay of proceedings on the ground that another court is more appropriate to hear the matter. (Note 78) The court has said that in such cases the interests of justice are paramount, and have adopted an approach that is similar to that of the House of Lords in Spiliada Maritime Corp v Cansulex Ltd. (Note 79) There is no presumption in favour of the plaintiff's choice of court.

In relation to service outside of Australia, leave of the issuing court will be required. Generally, each of the grounds (Note 80) on which service outside of Australia will be authorised require some connection between the jurisdiction and the cause of action. A connection can be established in relation to the performance of obligations in, or other issues relating to, a contract with some connection to the jurisdiction, where a tort is committed within the jurisdiction, breach of a federal statute (and in some cases a state statute), issues relating to land within the jurisdiction, where the remedy sought is an injunction to restrain performance of an act within the jurisdiction, for the administration of an estate of a person within the jurisdiction, proceedings for the execution of trusts governed by the law of the jurisdiction, as a member of a corporation formed or carrying on part of its affairs in the jurisdiction, relate to arbitration brought within the jurisdiction. Submission and residence are also recognised, as are cases where the defendant is a necessary and proper party to an action against a person served within the jurisdiction.

In these cases, however, a different approach has been taken when the defendant seeks a stay of proceedings on forum non conveniens grounds. The High Court has stated that in such cases it will not consider whether there is a more appropriate forum to hear the matter. Rather, it is up to the defendant in such a case to prove that the forum chosen by the plaintiff is 'clearly inappropriate'. (Note 81) In effect, then, there is a strong presumption in favour of the plaintiff's choice of forum.

While each jurisdiction in the United States has rules in relation to the jurisdiction of its courts, these rules must conform with the United States Constitution, in particular the due process clause. The Supreme Court has interpreted this clause to mean that there must be minimum contacts between a state and the individual, in order that the state has jurisdiction over a matter in which that individual is concerned. (Note 82) While presence in the jurisdiction would be sufficient, it is not necessary in order for minimum contacts to be established. Jurisdiction over the defendant must not offend fair play and substantive justice. The mere fact that an individual has contracted with an out of state party is not sufficient; the details of the contract including performance must be evaluated. (Note 83) There is a difference between 
a defendant who deliberately chooses to do business in the jurisdiction (in which jurisdiction will likely be established), and a defendant whose products might simply have been used in products sold in the jurisdiction (not sufficient of itself to attract jurisdiction). (Note 84)

Forum non conveniens applications will be dealt with on a similar basis to that described elsewhere. The relevant issue is whether another forum is more convenient, by considering where the evidence is, availability of compulsory process for the attendance of the unwilling, the cost of obtaining attendance of willing witnesses, and all other practical issues that would make trial of the case easy, expeditious and inexpensive, whether any judgment obtained would be enforceable, and relative advantages and obstacles to a fair trial. The public interest is also relevant. (Note 85) There is a strong presumption in favour of the plaintiff's choice of forum. (Note 86)

\subsection{Commentary on Commission's Proposal}

There is much to commend the Commission's proposal to adopt the Uniform Law Conference of Canada approach. As discussed above, much confusion and criticism continues to surround the 'real and substantial connection' test, so it is useful to provide a list of specific examples where such a connection will be presumed. This is similar to the European approach discussed above. Such an approach should increase certainty in the application of the test, and allow clients to be advised with a higher degree of accuracy than currently is the case in relation to jurisdiction questions. The approach balances some certainty with flexibility, by not making the examples given exhaustive, and by allowing either the plaintiff to show that despite the situation not being specifically mentioned, such connection does exist, or the defendant to show that, despite the situation not being specifically mentioned, such connection does not exist. The proposals will clear up some existing ambiguity in this area, by clarifying that the approach is to be adopted to both interprovincial and international matters, and that the real and substantial connection test is not all-encompassing.

I am not in favour of the aspect of the European approach that favours adoption of the domicile of the defendant as a default jurisdictional rule. It may be that other rules were considered 'too unbalanced, and not sufficiently concerned with the legitimate interests of the defendant'. (Note 87) However, the European approach risks being found not to be sufficiently concerned with the legitimate interests of the plaintiff. Why should the plaintiff be forced to conduct suit where the defendant happens to be domiciled, particularly where the evidence or witnesses are elsewhere, the defendant's domicile is a significant distance from the plaintiff's domicile etc? Accepting that no position in this regard is perfect, in my view, this issue is best resolved with the presumptions with flexibility approach advocated in the Uniform Law Conference of Canada approach, together with choice of law rules favouring the law of the place of the wrong (in tort cases), a broad conception of what is substantive, and continued application of the forum non conveniens principle.

Further, in mirroring the existing common law rules regarding forum non conveniens, the suggested approach is commendable. Such an approach is well known and has worked effectively. It is not suggested that Manitoba take the Australian approach to forum non conveniens applications, which has been criticised for its parochial nature. (Note 88) However, perhaps Canada should consider a regime like the Australian Service and Execution of Process Act, whereby the need for a connection is dispensed with where there is a question of jurisdiction in relation to a defendant present in Canada but not in the jurisdiction in which the matter is to be heard. Some of the American cases mentioned can provide further guidance in future as to factors relevant to the decision as to whether a 'real and substantial connection' exists. The courts or the legislators should also clarify whether the list of factors given in Muscutt should be used in future.

\section{Conclusion}

The Commission's proposals should generally be supported. The suggested introduction of a flexible exception for the choice of law rule in tort is sensible, and the need for it borne out by the cases. Specific provision could be made for situations where the plaintiff and defendant live in the same jurisdiction, and that jurisdiction is not the place of the wrong. I support the Commission's re-assertion of Tolofson in relation to the substantive nature of limitations periods. The Commission's adoption of the Uniform Law Conference of Canada position on jurisdiction questions is also sound. It clears up some areas of ambiguity and disagreement. I have suggested some issues that might require some further clarification, and that (subject to constitutional constraints), federal legislative action might be sensible in cases involving jurisdiction questions facing a court where the defendant is in Canada but in a different province in order to streamline process.

\section{References}

Ailes, E. (1941). 'Substance and Procedure in the Conflict of Laws' 39 Michigan Law Review 392.

American Law Institute. (1971). Restatement, Second, Conflict of Laws.

Beckett, W E. (1934). 'The Question of Classification in Private International Law' 15 British Yearbook of International Law 46. 
Black, V and Walker, J. (2003). 'The Deconstitutionalization of Canadian Private International Law' 21 Supreme Court Law Review 181.

Briggs, A and Rees, P. (2005). Civil Jurisdiction and Judgments.

Carruthers, J. (2004). 'Substance and Procedure in the Conflict of Laws: A Continuing Debate in Relation to Damages' 53 International and Comparative Law Quarterly 691.

Castel, J G. (1995). 'Back to the Future! Is the New Rigid Choice of Law Rule for Interprovincial Torts Constitutionally Mandated?' 33 Osgoode Hall Law Journal 35.

Cook, W W. (1933). 'Substance and Procedure in the Conflict of Laws' 42 Yale Law Journal 323. Dicey, Morris and Collins on the Conflict of Laws (2006) $14^{\text {th }}$ edition.

Dougherty, C. (2007). 'Private International Law: Harding v Wealands' 56 International and Comparative Law Quarterly 443.

Gray, A. (2004). 'Flexibility in Conflict of Laws Multistate Torts Cases: The Way Forward in Australia' 23 University of Queensland Law Journal 435.

Gray, A. (2007). 'The Rise of Renvoi in Australia: Creating the Theoretical Framework' 30(1) University of New South Wales Law Journal 103.

Gray, A. (2008). 'Giving Substance to Substance' 4(2) Journal of Private International Law 279.

Gray, A (2009) 'Forum Non Conveniens in Australia: A Critical Comparative Comparison' 38(4) Common Law World Review (in press)

James, E. (2001). 'John Pfeiffer Pty Ltd v Rogerson: The Certainty of Federal Choice of Law Rules for Intranational Torts: Limitations, Implications and a Few Complications' 23 Sydney Law Review 145.

Keyes, M. (2005). Jurisdiction in International Litigation.

McEvoy, J P. (1995). 'Choice of Law in Torts: The New Rule’ 44 University of New Brunswick Law Journal 211.

Manitoba Law Reform Commission. (2009). Private International Law.

Monestier, T. (2008). 'A Real and Substantial Mess: The Law of Jurisdiction in Canada' 33 Queen's Law Journal 179

Mortensen, R. (2006). 'Troublesome and Obscure: The Renewal of Renvoi in Australia' 2(1) Journal of Private International Law 1.

Mortensen, R. (2006). 'Homing Devices in Choice of Tort Law: Australian, British and Canadian Approaches' 55 International and Comparative Law Quarterly 839

Panagopoulos, G. (2005). 'Substance and Procedure in Private International Law' 1 Journal of Private International Law 69.

Pitel, S and Dusten, C. (2006). 'Lost in Transition: Answering the Questions Raised by the Supreme Court of Canada's New Approach to Jurisdiction' 85 Canadian Bar Review 61.

Stephens, P. (2007). 'Spinning Sosa: Federal Common Law, the Alien Tort Statute and Judicial Restraint' 25 Boston University International Law Journal 1.

Symeonides, S. (2006). 'Choice of Law in the American Courts in 2006: Twentieth Annual Survey' 54 American Journal of Comparative Law 697.

Walker, J. (1995). 'Choice of Law in Tort: The Supreme Court of Canada Enters the Fray' 111 Law Quarterly Review 397.

Walker, J. (2006). 'Castillo v Castillo: Closing the Barn Door' 43 Canadian Business Law Journal 487.

Walsh, C. (1988). 'A Stranger in the Promised Land? The Non-Resident Accident Victim and the Quebec No-Fault Plan’ 37 University of New Brunswick Law Journal 173.

\section{Notes}

Note 1. Private International Law, Report 119 (January 2009).

Note 2. (1870) 6 LR QB 1, 28-29.

Note 3. In the United Kingdom - Chaplin v Boys [1971] AC 356; in Australia - McKain v $R$ W Miller and Co (SA) Pty Ltd (1991) 174 CLR 1; and in New Zealand - Baxter v RMC Group PLC [2003] 1 NZLR 304.

Note 4. McLean v Pettigrew [1945] S.C.R. 62. 
Note 5. [1994] 3 S.C.R. 1022 (the decision was unanimous, subject to a reservation by Sopinka and Major JJ of possible exceptions to the general rule favouring the law of the place of the wrong in some cases).

Note 6. 1049-1052.

Note 7. 1055-1062

Note 8. La Forest, Gonthier, Cory, McLachlin and Iacobucci JJ, Sopinka and Major JJ dissenting on this point.

Note 9. 1054 (La Forest J, with whom Gonthier Cory McLachlin and Iacobucci JJ agreed); McEvoy, J P (1995) 'Choice of Law in Torts: The New Rule' 44 University of New Brunswick Law Journal 211

Note 10. Hanlan v Sernesky (1998) 38 O.R (3d) 479 (C.A), where the dispute involved an accident in Minnesota, but both parties lived in Ontario, the relevant insurance policy was issued in Ontario, there was no real connection with Minnesota other than the fact the accident occurred there (the court also took into account the claim was not recognised by the law of Minnesota); Wong $v$ Wei (1999) 45 C.C.L.T (2d) 105 (British Columbia Supreme Court), involving a claim between two British Columbia residents over an accident that occurred in California, again there was little to connect the parties to California other than the fact the accident occurred there); and Lebert v Skinner Estate (2001) 53 O.R. (3d) 559 (S.C.J.). Examples where the exception was argued but not applied in international cases include Wong $v$ Lee (2002) 58 O.R (3d) 398, Britton v O'Callaghan (2002) 62 O.R. (3d) 95 (C.A) and Somers v Fournier (2002) 60 O.R (3d) 225 (C.A) and in domestic cases Brown v Kerr-McDonald (2002) 326 A.R 267 (Q.B) and Soriano v Palacios (2005) 225 D.L.R $\left(4^{\text {th }}\right) 359$ (Ont C.A).

Note 11. Lau v Li (2001) 53 O.R.(3d) 727 (S.C.J).

Note 12. Renvoi is specifically excluded. No exception applies in respect of defamation actions, unlike the legislation on which the Commission's recommendations are based, the Private International Law (Miscellaneous Provisions) Act 1995 (UK). Reforms to the lex loci delicti rule were also recommended by Walsh, C (1988) 'A Stranger in the Promised Land?: The Non-Resident Accident Victim and the Quebec No-Fault Plan' 37 University of New Brunswick Law Journal 173 .

Note 13. [1971] AC 356.

Note 14. 191 NE (2d) 279 (1963).

Note 15. [1971] AC 356.

Note 16. S12(1) and (2).

Note 17. Article 4(1). It specifically states that the law of the place where the events giving rise to the damage, or where the indirect consequences occur, is not determinative.

Note 18. This is similar to the provisions of the Hague Convention on Traffic Accidents, which provides for an exception to the application of the law of the place of the wrong where all parties involved in the accident are from the forum.

Note 19. Article 4(3).

Note 20. (1988) 169 CLR 41, 76 (Mason CJ) and 162 (Toohey J).

Note 21. (2000) 203 CLR 503.

Note 22. 538 (Gleeson CJ Gaudron McHugh Gummow and Hayne JJ). This decision has been criticised; see for example Gray, A (2004) 'Flexibility in Conflict of Laws in Multistate Tort Cases: The Way Forward in Australia' 23 University of Queensland Law Journal 435; James, E (2001) 'John Pfeiffer Pty Ltd v Rogerson: The Certainty of Federal Choice of Law Rules for Intranational Torts: Limitations, Implications and a Few Complications' 23 Sydney Law Review 145.

Note 23. Regie National des Usines Renault SA v Zhang (2002) 210 CLR 491, 519 (Gleeson CJ Gaudron McHugh Gummow and Hayne JJ); Kirby J specifically left open the question of a flexible exception in international tort cases (535).

Note 24. 1054.

Note 25. (2005) 223 CLR 331.

Note 26. Gleeson CJ (341-342), Gummow and Hayne JJ (364), and Kirby and Heydon JJ (389, 420) favoured a 'double renvoi' approach, Callinan J a single renvoi approach (414). McHugh J dissented (349). The case has attracted criticism: see for example Mortensen, R (2006) 'Troublesome and Obscure: The Renewal of Renvoi in Australia' 2(1) Journal of Private International Law 1; Gray, A (2007) 'The Rise of Renvoi in Australia: Creating the Theoretical Framework' 30(1) University of New South Wales Law Journal 103. 
Note 27. Callinan J 'no matter which solution is adopted by Australian courts, the result will not be entirely satisfactory intellectually and in logic. This does not stem wholly however from the unwillingness of the Court to recognise in Zhang what in hindsight might have resolved this case, a flexible exception ... but from the fact that absolute rules however apparently certain and generally desirable they may be, almost always in time come to encounter a hard and unforeseen case' (413).

Note 28. Mortensen, R (2006) 'Homing Devices in Choice of Tort Law: Australian, British and Canadian Approaches' 55 International and Comparative Law Quarterly 839, 873.

Note 29. American Law Institute Restatement First, Conflict of Laws (1934).

Note 30. 12 NY 2d 477 (1962).

Note 31. 481; in that case, New York was where the driver and passenger lived, where the car was kept, licensed and insured, and the place where the weekend journey was to begin and end.

Note 32. American Law Institute Restatement Second, Conflict of Laws (1971) s145(2).

Note 33. Symeonides, S (2006) 'Choice of Law in the American Courts in 2006: Twentieth Annual Survey' 54 American Journal of Comparative Law 697, 713.

Note 34: (1995) 'Back to the Future: Is the New Rigid Choice of Law Rule for Interprovincial Torts Constitutionally Mandated?’ 33 Osgoode Hall Law Journal 35, 68.

Note 35.1073.

Note 36. This problem was alluded to in Mortensen, R (2006) 'Homing Devices in Choice of Tort Law: Australian, British and Canadian Approaches' 55 International and Comparative Law Quarterly 839, 868-870; this exception might be limited to what Cardozo J referred to as laws that 'shock our sense of justice or menace the public welfare, or violates some fundamental principle of justice, some prevalent conception of good morals, some deep-rooted tradition of the common weal': Loucks $v$ Standard Oil Co of New York 120 NE 198, 202 (1918).

Note 37. Ailes, E (1941) 'Substance and Procedure in the Conflict of Laws' 39 Michigan Law Review 392.

Note 38. 1067-1073; Walker, J (1995) 'Choice of Law in Tort: The Supreme Court of Canada Enters the Fray’ 111 Law Quarterly Review 397, 398.

Note 39. For example, in Newfoundland and Labrador the Limitation of Actions legislation declares that it applies to actions in the respective provinces to the exclusion of the limitation periods of other jurisdictions: S.N.L 1995, c. L-16.1. The rule in Saskatchewan is similar (S.S 2004, c. L-16.1); and apparently in Alberta (R.S.A 2000, c L-12), though that provision has been interpreted not to override the limitation period specified by the law of the place of the wrong: Castillo v Castillo (2004) 376 A.R 224 (S.C.C); Janet Walker (2006) 'Castillo v Castillo: Closing the Barn Door' 43 Canadian Business Law Journal 487.

Note 40. Vogler $v$ Szendroi [2008] NSCA 18; on the basis that the question of limitations only arose due to the commencement of a claim in accord with the rules of the forum (however, with respect, all conflicts issues arise only because a claim is commenced in accordance with forum rules - this reasoning could be used to justify applying forum law to other matters such as liability and remedies).

Note 41. S.O 2002 c.24 Sch. B, s23.

Note 42. Conflict of Laws (1896) p712.

Note 43. Dicey, Morris and Collins on the Conflict of Laws (2006) $14^{\text {th }} \mathrm{ed}$, p178.

Note 44. Foreign Limitation Periods Act 1985 (UK) s1(1)(a); Prescription and Limitation (Scotland) Act 1984 (UK) s23A. Notwithstanding, the Court of Sessions has suggested that limitation periods could be procedural: Milne $v$ Moores [1999] Scot CS 305; cf Barks v CGU Insurance Plc [2004] Scot CS 241.

Note 45. Harding $v$ Wealands [2006] 3 WLR 83; C Dougherty (2007) 'Private International Law: Harding $v$ Wealands' 56 International and Comparative Law Quarterly 443.

Note 46. (1991) 174 CLR 1 (Brennan Dawson Toohey and McHugh JJ), Mason CJ Deane and Gaudron JJ dissenting.

Note 47. 25. Cook also saw the distinction in terms of efficiency: Cook, W W (1933) 'Substance and Procedure in the Conflict of Laws' 42 Yale Law Journal 323, 343-344. and see Beckett, W E (1934) 'The Question of Classification in Private International Law' 15 British Yearbook of International Law 46, 71; and Carruthers, J (2004) 'Substance and Procedure in the Conflict of Laws: A Continuing Debate in Relation to Damages' 53 International and Comparative.Law Quarterly 691, 710; Panagopoulos, G (2005) 'Substance and Procedure in Private International Law' 1 Journal of Private International Law 69.

Note 48. 50. 
Note 49. (2000) 203 CLR 503.

Note 50. 543; see Kirby J to like effect 554; see Panagopoulos, G (2005) 'Substance and Procedure in Private International Law' 1 Journal of Private International Law 69; Gray, A (2008) 'Loss Distribution Issues in Multinational Tort Claims: Giving Substance to Substance' 4(2) Journal of Private International Law 279.

Note 51. See, for example, the Choice of Law (Limitation Periods) Act 1993 (NSW) and comparable legislation in other States and Territories.

Note 52. In Cole v Mileti (1998) 133 F 2d 433, the Court of Appeals (Sixth Circuit) applied the forum's limitation period to a claim resulting from an agreement to which the parties had agreed Californian law would apply. Notwithstanding this, the court applied the limitation period of the forum (Ohio). The distinction between statutes that bar the remedy and those that extinguish the right is maintained in some states - see for example Gomez v ITT Educational Services Inc 71 SW 3d 542 (Arkansas, 2002).

Note 53. 538 US 488 (2003).

Note 54. 465 F.3d 992 (9 ${ }^{\text {th }}$ Cir, 2006).

Note 55. Sam v Sam 134 P. 3d 761 (N.M 2006).

Note 56. Morguard v De Savoye (1990) 76 D.L.R $\left(4^{\text {th }}\right) 256$ (S.C.C).

Note 57. The connection between the forum and the plaintiff's claim, the connection between the forum and the defendant, unfairness to the defendant in assuming jurisdiction, unfairness to the plaintiff in not assuming jurisdiction, the involvement of other parties to the suit, the court's willingness to recognise and enforce an extra-provincial judgment rendered on the same jurisdictional basis, whether the case is interprovincial or international in nature, and comity and standards, of jurisdiction, recognition and enforcement prevailing elsewhere: Muscutt v Courcelles (2002) 213 DLR $\left(4^{\text {th }}\right) 577$ (Ontario Court of Appeal).

Note 58. In Spar Aerospace Ltd v American Mobile Satellite Corp [2002] 4 S.C.R 205, a unanimous Supreme Court appeared to confine the real and substantial connection test to interprovincial matters only (231-233). This was subject to criticism: see for example Black, V and Walker, J (2003) 'The Deconstitutionalization of Canadian Private International Law' 21 Supreme Court Law Review 181, 188-192, Pitel, S and Dusten, C (2006) 'Lost in Transition: Answering the Questions Raised by the Supreme Court of Canada's New Approach to Jurisdiction' 85 Canadian Bar Review 61. In Beals $v$ Saldanha [2003] 3 S.C.R 416, a majority of the court said the test was applicable to both interprovincial and international matters (McLachlin CJ Gonthier, Major, Bastarache, Arbour, Deschamps, Iacobucci and Binnie JJ, LeBel J dissenting).

Note 59. In Beals v Saldanha [2003] 3 S.C.R 416, Major J held that a 'real and substantial connection is the overriding factor in the determination of jurisdiction', and that 'presence of more of the traditional indicia of jurisdiction (attornment, agreement to submit, residence and presence in the foreign jurisdiction) will serve to bolster the real and substantial connection to the action or parties'.

Note 60. As Monestier puts it, 'Muscutt has essentially transformed the question of whether a court can hear a case (jurisdiction simpliciter) into the question of whether a court should hear a case (forum non conveniens). This has invited inconsistent results, increased uncertainty for litigants, and rendered the role of forum non conveniens largely redundant': (2008) 'A “Real and Substantial” Mess: The Law of Jurisdiction in Canada' 33 Queen's Law Journal 179.

Note 61 . They include the residence of the parties, witnesses and experts, the location of the material evidence, where the contract was negotiated and executed, the existence of proceedings pending between the parties in another jurisdiction, the location of the defendant's assets, the applicable law, advantages conferred upon the plaintiff by its choice of forum (if any), the interests of justice, the interests of the parties, and the need to have the judgment recognised in another jurisdiction: Lexus Maritime Inc v Oppenheim Forfait GmbH [1998] Q J No 2059 (QL), referred to with approval

Note 62. Spar Aerospace Ltd v American Mobile Satellite Corp [2002] 4 S.C.R 205, 238.

Note 63. [1987] 1 AC 460 (discussed below)

Note 64 . The Commission agrees with the add-on provision enacted by jurisdictions such as Yukon, to clarify that the presumptions are not conclusive.

Note 65. Section 6 provides that even when none of the factors exists, the Court retains a discretion to hear the proceeding if it considers that there is no other court in which the plaintiff can commence the proceeding, or the commencement of the proceeding in a court outside the province cannot reasonably be required.

Note 66. S7-9 clarify the meaning of residence for companies, partnerships and unincorporated associations respectively. A slight change to the way in which residence in relation to partnership is made by the Saskatchewan 
provision, considering the residence of an individual partner rather than where the partnership's central management occurs.

Note 67. S3.

Note 68 . The explanatory notes make clear that the meaning of 'real and substantial connection' is not confined by the rules of court.

Note 69. This point is made explicitly in the Yukon legislation, a precedent the Commission supports in its Report here.

Note 70. A proposed Hague Convention on Jurisdiction and Foreign Judgments in Civil and Commercial Matters did not materialise in that form, instead morphing into the Hague Convention on Choice of Court Agreements (2005). The Regulation applies to proceedings commenced after 1 March 2002 (Article 76).

Note 71. Article 5(1).

Note 72. Article 5(3) and (6); other sub-articles deal with maintenance issues, issues involving both tort/restitution claims and a criminal claim, and cargo salvage.

Note 73. Articles 9-14, 15-17 and 18-21 respectively.

Note 74. Article 27.

Note 75. Spiliada Maritime Corp v Cansulex Ltd [1987] 1 AC 460, 482-284 (Lord Goff). Other factors of lesser importance were mentioned, including the place in which the matter can be heard earliest, where there is greater scope for discovery, better recovery of damages and opportunity for enforcement, more generous limitation period etc.

Note 76. High Court of Australia Order 9; Federal Court of Australia Order 7.

Note 77. Jurisdiction of Courts (Cross-Vesting) Acts 1987 (Cth) s5.

Note 78. S20(4) of the Act states that relevant factors include the place of residence of the parties and the witnesses likely to be called in the proceedings, the place where the subject matter of the litigation is situated, the financial circumstances of the parties, any agreement between the parties about the court or the place in which the proceedings should be instituted, the law that would be most appropriate to apply in the proceedings, and whether a related or similar proceeding has been commenced against the person served or another person.

Note 79. [1987] 1 AC 640; Lubbe and Cape Plc [2000] UKHL 41; BHP Billiton Limited v Schultz (2004) 211 ALR 523.

Note 80. The rules are found in High Court Rules 1952, Federal Court Rules 1979, ACT Supreme Court Rules 1937, Northern Territory Rules of the Supreme Court, New South Wales Supreme Court Rules 1970, Queensland Uniform Civil Procedure Rules 1999, South Australia Supreme Court Rules 1987, Tasmania Rules of the Supreme Court 1965, Victoria Rules of the Supreme Court 1996, Western Australia Rules of the Supreme Court 1971. See Keyes, M Jurisdiction in International Litigation (2005)

Note 81. Voth v Manildra Flour Mills Pty Ltd (1990) 171 CLR 538.

Note 82. International Shoe Co v Washington 326 US 310 (1945); similarly, the question of minimum contacts affects the enforceability of the judgment against that individual. The Supreme Court of Canada agreed that the test was satisfied on the facts of Beals $v$ Saldanha [2003] 3 S.C.R. 416.

Note 83. Burger King Corp v Rudzewicz 471 US 462 (1985), World-Wide Volkswagen Corp et al v Woodson 444 US 286 (1980). It is beyond the scope of this article to consider the Alien Tort Statute in any detail; however for further reading see recently Sosa v Alvarez-Machain (2004) 542 US 692 and Stephens, P (2007) 'Spinning Sosa: Federal Common Law, the Alien Tort Statute and Judicial Restraint' 25 Boston University International Law Journal 1.

Note 84. Asahi Metal Industry Co Ltd v Superior Court of California, Solano County 480 US 102 (1987).

Note 85. Gulf Oil Corp v Gilbert 330 US 501 (1947).

Note 86. Piper Aircraft Co v Reyno 454 US 235 (1981).

Note 87. Briggs, A and Rees, P (2005) Civil Jurisdiction and Judgments $\mathrm{p} 2$.

Note 88. Mortensen, R (2006) 'Troublesome and Obscure: The Renewal of Renvoi in Australia' 2(1) Journal of Private International Law 1, 26. 